\title{
The Notion of Stability of a Differential Equation and Delay Differential Equation Model of HIV Infection of $\mathrm{CD}^{+}{ }^{\mathrm{T}}$-Cells
}

\author{
${ }^{1}$ Normah Maan \\ ${ }^{1}$ Department of Mathematical Sciences, Faculty of Science, \\ Universiti Teknologi Malaysia, Skudai, Johor Darul \\ Takzim, Malaysia. \\ 1․ㅏmahmaan@utm.my, normahmaan@gmail.com.
}

\author{
${ }^{2}$ Izaz Ullah Khan, ${ }^{3}$ Nor Atirah Izzah Zulkefli \\ ${ }^{2}$ CIIT Abbottabad, Pakistan. \\ ${ }^{3}$ Department of Mathematical Sciences, Faculty of Science, \\ Universiti Teknologi Malaysia, Skudai, Johor Darul \\ Takzim, Malaysia. \\ 2izaz1982@yahoo.co.uk, ${ }^{3}$ noratirahizzah@gmail.com.
}

\begin{abstract}
This research presents a deep insight to address the notion of stability of an epidemical model of the HIV infection of $\mathrm{CD4}^{+} \mathrm{T}$-Cells. Initially, the stability of an ordinary differential equation (ODE) model is studied. This is followed by studying a delay differential equation (DDE) model the HIV infection of $\mathrm{CD4}^{+} \mathrm{T}$-Cells. The available literature on the stability analysis of the ODE model and the DDE model of the $\mathrm{CD4}^{+} \mathrm{T}$-Cells shows that the stability of the models depends on the basic reproduction number " $\mathbf{R}_{\mathbf{0}}$ ". Accordingly, for the basic reproduction number $\mathbf{R}_{\mathbf{0}}$ $<1$, the model is asymptotically stable, whereas, for $R_{0}>1$, the models are globally stable. This research further studies the stability of the models and address the lower possible stability limits for the infection rate of $\mathrm{CD}^{+} \mathrm{T}$-Cells with virus and the reproduction rate of infectious $\mathrm{CD4}^{+} \mathrm{T}$-Cells, respectively. Accordingly, the results shows that the lower possible limits for the infection rate of $\mathrm{CD4}^{+} \mathrm{T}$-Cells with virus are $0.0000027 \mathrm{~mm}^{-3}$ and $0.000066 \mathrm{~mm}^{-3}$ for the ODE and DDE models, respectively. Again, the lower stability limits for the reproduction rate of infectious $\mathrm{CD4}^{+} \mathrm{T}$-Cells with virus are $12 \mathrm{~mm}^{3} \mathrm{day}^{-1}$ and 273.4 $\mathrm{mm}^{3} \mathrm{day}^{-1}$ for the ODE and DDE models, respectively. The research minutely studies the stability of the models and gives a deep insight of the stability of the ODE and DDE models of the $\mathrm{HIV}$ infection of $\mathrm{CD4}^{+} \mathrm{T}$-Cells with virus.
\end{abstract}

Keywords-HIV infection, Stability analysis, CD4 ${ }^{+}$T-Cells, $O D E$ and DDE Models of HIV infections.

\section{INTRODUCTION}

In order to address the immunological response to infection with human immunodeficiency virus (HIV), many mathematical models have been developed [1-11]. These models address the infection with human immunodeficiency virus (HIV) as linear / nonlinear ordinary differential equation models, with or without delay. Most of them focus to explain the interactions among immune cells, infected cells, viruses, and target cells at inter molecular level. The simple HIV models can help better understand the disease and the underlying kinetics behind the various drug therapies to cure it. Thus the simplest HIV model is given as:

$$
\frac{d V}{d t}=P-c V
$$

The variables $P, c$ and $V$ denote the rate of virus production, clearance rate constant and concentration of the virus, respectively. A more reasonable model for the dynamics of the $\mathrm{CD} 4^{+} \mathrm{T}$-cells is given in equation (2).

$\dot{T}=s-d T+a T\left(1-\frac{T}{T_{\max }}\right)$

In equation (2), " $s$ " denotes the production rate of new immune T-cells in the body and " $d$ " represents the death rate of virus per T-cell. Note that the immune T-cells can also be produced by proliferation of the available T-cells in the body. Thus in (2), " $a$ " represents the maximum proliferation rate and " $T_{\max }$ " denotes the maximum population of the immune $\mathrm{T}$ cells. Note that this the maximum threshold population of the immune T-Cells and the proliferation automatically shuts off at this level.

The reproduction process of most of the viruses is simple and straight forward. Most of the viruses copies their Deoxyribonucleic Acid (DNA) and insert a copy into the DNA of the host cells. On stimulation, the copies of the viruses are reproduced. The reproduction of the HIV virus does not take place independently [12]. The HIV virus targets the $\mathrm{CD}^{+} \mathrm{T}$ Cells, when they are in close contact. A special kind of protein on the surface of the HIV virus has a great attraction for the $\mathrm{CD}^{+}$protein on the surface of the immune T-Cells. Due to the process of binding, the HIV viruses are injected into the TCells. An unanswered mystery of the medical science is the retroviral nature of the HIV virus. Unlike most of the viruses, the HIV virus first carries a copy of its RNA, which is then transcribed into DNA. After duplication of DNA of the viruses by the host cells, the viruses reassemble and new virus particles bud from the surface of the host cells. The process of budding is slow paced, sparing, bursting and killing the host cells.

The process of HIV virus infection is not simply clear and straight forward. The medical sciences still have to address the final collapse of the immune system due to the infection of the 
virus causing death. However, it is collectively agreed upon, that the process take place in four stages. Firstly, the introduction of the virus into the body. Secondly, the initial short period transient state, when the T-Cells and the virus concentrations are very high. This is followed by the disease steady state, called clinical latency, with extremely large number of viruses and T-Cells with incredible interactions and dynamics. The final stage is the called AIDS, in which, the population of the T-Cells drops to very low numbers (zero), whereas, that of viruses grows without bounds, causing death. However, a controversy still exists to address whether the HIV virus directly kills all the immune T-Cells in the last stage or some of mechanism is at work.

To cure the disease, the widely used methodologies are the anti-retroviral therapies. An evident example is the chemotherapy, through which an adequate part of the infected cells are transformed into target cells at the initial introduction of the viruses in the T-Cells. The dynamics between the effects of drugs on the virus was also studied [13]. At the initial first phase of one / two weeks, the virus population fell down dramatically, followed by a slower second phase [13]. The reason for this may be the noncytopathic nature of HIV virus, meaning that the infectious cells can be lost through death, immune killing or via proper cure, e.g. loss of cccDNA. The second phase slow dynamics is due to the fact that antiviral therapy only partially stops the production of the new viruses, resulting in a drop in the HIV RNA, but in reality an active immune response is required for the second phase decline and loss of cells producing virus [13].

This research tries to present a deep insight for the stability of an epidemic model of the HIV infection of $\mathrm{CD}^{+}$ T-Cells. Initially, the stability of an ordinary differential equation (ODE) model is studied. This is followed by studying a delay differential equation (DDE) model the HIV infection of CD4 ${ }^{+}$T-Cells. The stability of these models was addressed in [12]. The hallmark of the study is that it further studies the stability of the models and addresses the lower possible stability limits for the infection rate of $\mathrm{CD} 4^{+} \mathrm{T}$-Cells with virus and the reproduction rate of infectious $\mathrm{CD}^{+} \mathrm{T}$-Cells, respectively. Thus the results suggest the lower possible limits for the infection rate of $\mathrm{CD}^{+} \mathrm{T}$-Cells with virus for the ODE and DDE models, respectively. Furthermore, it also gives the lower stability limits for the reproduction rate of infectious $\mathrm{CD}^{+}$T-Cells with virus for the ODE and DDE models, respectively. In this way, the research deeply studies the stability of the ODE and DDE models of the HIV infection of $\mathrm{CD}^{+} \mathrm{T}$-Cells with virus.

\section{THE ODE MODEL}

An epidemic model of HIV infection of $\mathrm{CD}^{+} \mathrm{T}$-Cells along with a cure rate is presented as:

$$
\frac{d T}{d t}=s-d T+a T\left(1-\frac{T}{T_{\max }}\right)-\beta T V+\rho I
$$

$$
\begin{aligned}
& \frac{d I}{d t}=\beta T V-(\delta+\rho) I \\
& \frac{d V}{d t}=q I-c V
\end{aligned}
$$

Along with the initial conditions, $T(0)>0, I(0)>0, V(0)>0$.

Here, " $T$ " represent the target cells, which, after an interaction with virus " $V$ ", get infected. Furthermore, " $P$ " represents the number of infected cells. The variable $\beta$ denotes the infection rate constant, whereas, $\beta T V$, is the rate of infection of $\mathrm{CD}^{+} \mathrm{T}$-Cells with virus. Moreover, " $s$ " denotes the production rate of new immune T-cells in the body and " $d$ " represents the death rate of virus per T-cell. Also " $a$ " represents the maximum proliferation rate and " $T_{\max }$ " denotes the maximum population of the immune T-cells. The other model parameters of the model are given in Table1.

TABLE I.

\begin{tabular}{|c|c|c|}
\hline Parameter & Description & Value \\
\hline$T$ & Target $\mathrm{CD}^{+}{ }^{+} \mathrm{T}-$-Cells & $50_{m^{-3}}$ \\
\hline V & Infected CD4 ${ }^{+}$T-Cells. & 80 \\
\hline$I$ & Population of HIV RNA. & $100 \mathrm{~mm}^{-3}$ \\
\hline$s$ & Birth rate of $\mathrm{CD} 4^{+} \mathrm{T}$-Cells. & $5 m^{-3} d a y^{-1}$ \\
\hline$d$ & Death rate of $\mathrm{CD} 4^{+} \mathrm{T}$-Cells. & $0.01 d_{d a y^{-1}}$ \\
\hline$a$ & Growth rate of $\mathrm{CD}^{+}{ }^{+} \mathrm{T}-\mathrm{Cells}$. & 0.8 day $^{-1}$ \\
\hline$T_{\max }$ & Maximum population of $\mathrm{CD} 4^{+} \mathrm{T}-\mathrm{Cell}$ s. & $120 \mathrm{~mm}^{3} \mathrm{day}^{-1}$ \\
\hline$\beta$ & Infection rate of $\mathrm{CD} 4^{+} \mathrm{T}$-Cells with virus. & $0.00024 \mathrm{~mm}^{-3}$ \\
\hline$\rho$ & Cure rate of the disease. & $0.01 d_{d a y^{-1}}$ \\
\hline$\delta$ & $\begin{array}{l}\text { Death rate of the infectious } \mathrm{CD}^{+}{ }^{+} \mathrm{T}- \\
\text { Cells. }\end{array}$ & $0.4_{d a y^{-1}}$ \\
\hline$q$ & $\begin{array}{l}\text { Reproduction rate of infectious } \mathrm{CD}^{+} \mathrm{T}- \\
\text { Cells. }\end{array}$ & $100 m_{m^{3}}^{3} d a y^{-1}$ \\
\hline$c$ & Death rate of free virus. & 8 day $^{-1}$ \\
\hline
\end{tabular}

PARAMETERS FOR THE

VIRAL SPREAD MODEL.

\section{THE DDE MODEL}

To describe the dynamics of the interaction of the healthy cells with virus a discreet time delay model given as follows:

$\frac{d T}{d t}=s-d T+a T\left(1-\frac{T}{T_{\max }}\right)-\beta T(t-\tau) V(t-\tau)+\rho I$

$\frac{d I}{d t}=\beta T(t-\tau) V(t-\tau)-(\delta+\rho) I$ 
$\frac{d V}{d t}=q I-c V$

This model assumes that at time $t$, only the healthy infected by the HIV virus $\tau$ time before " $(t-\tau)$ " get infected. This restriction changed the incidence term for the healthy cells from $\beta T V$ to $\beta T(t-\tau) V(t-\tau)$ in the model. Moreover, the model in Equations (6-8) satisfy the initial conditions: $T\left(\theta_{0}\right)>T_{0}, I\left(\theta_{0}\right)>I_{0}, V\left(\theta_{0}\right)>V_{0}$ with $\theta_{0} \varepsilon[-\tau, 0]$. Note that all the parameters of the model in (3-5) and (6-8) are the same except the introduction of discrete time delay $\tau$.

\section{STABILITY OF THE ODE AND DDE MODELS}

This section is devoted to analyze the stability of the ODE and DDE models of the HIV infection of $\mathrm{CD}^{+}{ }^{+}$-Cells with virus.

The ODE model presented in equations (3-5) is asymptotically stable according as the basic reproduction number $\mathrm{R}_{0}<1$, whereas, for $\mathrm{R}_{0}>1$, the models are globally stable [12]. Here, $R_{0}=\frac{T_{0}}{\bar{T}}=\frac{\left(T_{\max } \beta q\right)\left[(a-d)+\sqrt{\left.(a-d)^{2}+\left(\frac{4 a s}{T_{\max }}\right)\right]}\right.}{2 a c(\delta+\rho)}$, with, $T_{0}=\left(\frac{T_{\max }}{2 a}\right)\left[(a-d)+\sqrt{\left.(a-d)^{2}+\left(\frac{4 a s}{T_{\max }}\right)\right]}\right.$, and $\bar{T}=\frac{c(\delta+\rho)}{\beta q}$.

On analysis, we come to know that stability of the model can be disturbed by a very small number or a large number. For the very small number, this research takes the infection rate of $\mathrm{CD}^{+}$T-Cells with virus " $\beta$ " and for the large number the reproduction rate of infectious $\mathrm{CD} 4{ }^{+} \mathrm{T}-\mathrm{Cells}$ " $q$ ", respectively. Table (II) summaries the lower possible stability limits for these parameters and are visualized in Fig. 1 and Fig. 2, respectively. Table (II) shows that the lower possible stability limit for the infection rate of $\mathrm{CD}^{+}{ }^{+} \mathrm{T}$-Cells with HIV virus is $0.0000027 \mathrm{~mm}^{-3}$ and the lower limit for the reproduction rate of infectious $\mathrm{CD}^{+} \mathrm{T}$-Cells with virus is $12 \mathrm{~mm}^{3} \mathrm{day}^{-1}$ for the ODE model.

TABLE II.

STABILITY ANALYSIS FOR THE ODE MODEL.

\begin{tabular}{|l|c|c|}
\hline Parameter & Value & $R_{0}=\frac{T_{0}}{\bar{T}}=\frac{\left(T_{\max } \beta q\right)\left[(a-d)+\sqrt{(a-d)^{2}+\left(\frac{4 a s}{T_{\max }}\right)}\right.}{2 a c(\delta+\rho)}$ \\
\hline$\beta \mathrm{mm}^{-3}$ & 0.000001 & 0.726 (Unstable) \\
\cline { 2 - 3 } $\begin{array}{l}\text { Infection rate of } \\
\mathrm{CD} 4^{+} \text {T-Cells with } \\
\text { virus. }\end{array}$ & 0.000002 & 0.907 (Unstable) \\
\cline { 2 - 3 } & 0.0000025 & 0.944 (Unstable) \\
\cline { 2 - 3 } & 0.0000026 & 0.980 (Unstable) \\
\cline { 2 - 3 } & 0.0000027 & 1.016 (Stable) \\
\cline { 2 - 3 } $\begin{array}{l}\text { q } \text { mm }^{3} \text { day } \\
\text { Reproduction rate } \\
\text { of infectious CD4 }\end{array}$ & 0.000003 & 1.089 (Stable) \\
\cline { 2 - 3 } & 11 & 0.958 (Unstable) \\
\cline { 2 - 3 } & 25 & 1.045 (Stable) \\
\hline
\end{tabular}

\begin{tabular}{|l|c|c|}
\hline T-Cells. & 50 & 2.74 (Stable) \\
\cline { 2 - 3 } & 100 & 8.71 (Stable) \\
\cline { 2 - 3 } & 500 & 43.57 (Stable) \\
\hline
\end{tabular}

Again, the DDE model in equations (6-8) is asymptotically stable according as the basic reproduction number $\mathrm{R}_{0}<1$, whereas, for $\mathrm{R}_{0}>1$, the models are globally stable [12].

In this case, the basic reproduction number ${ }_{R_{0}}=\frac{T_{0}}{\bar{T}}=\frac{\left(T_{0} \beta q\right)}{c(\delta+\rho)}$.

Table (III) summaries the lower possible stability limits for the infection rate of $\mathrm{CD}^{+} \mathrm{T}$-Cells with virus " $\beta$ " and for the reproduction rate of infectious $\mathrm{CD} 4^{+} \mathrm{T}-\mathrm{Cells}$ " $q$ ", respectively. The lower possible stability limits for these parameters are visualized in Fig. 3 and Fig. 4, respectively. From Table (III), the lower stability limit for the infection rate of $\mathrm{CD}^{+} \mathrm{T}$-Cells with virus is $0.000066 \mathrm{~mm}^{-3}$, whereas, for the reproduction rate of infectious $\mathrm{CD}^{+} \mathrm{T}$-Cells with virus is $273.4 \mathrm{~mm}^{3} \mathrm{day}^{-1}$ for the DDE model.

TABLE III.

STABILITY ANALYSIS FOR THE ODE MODEL.

\begin{tabular}{|c|c|c|}
\hline Parameter & Value & $R_{0}=\frac{T_{0}}{\bar{T}}=\frac{\left(T_{0} \beta q\right)}{c(\delta+\rho)}$ \\
\hline \multirow{6}{*}{$\begin{array}{l}\beta \mathrm{mm}^{-3} \\
\text { Infection rate of } \\
\mathrm{CD}^{+} \mathrm{T}-\mathrm{T} \text {-Cells with } \\
\text { virus. }\end{array}$} & 0.000024 & 0.365 (Unstable) \\
\hline & 0.00005 & 0.7621 (Unstable) \\
\hline & 0.00006 & 0.914 (Unstable) \\
\hline & 0.000065 & 0.990 (Unstable) \\
\hline & 0.000066 & 1.006 (Stable) \\
\hline & 0.00007 & 1.06 (Stable) \\
\hline \multirow{6}{*}{$\begin{array}{l}q \mathrm{~mm}^{3} \text { day }^{-1} \\
\text { Reproduction rate } \\
\text { of infectious } \mathrm{CD}^{+} \\
\text {T-Cells. }\end{array}$} & 255 & 0.932 (Unstable) \\
\hline & 260 & 0.95 (Unstable) \\
\hline & 270 & 0.98 (Unstable) \\
\hline & 273.3 & 0.999 (Unstable) \\
\hline & 273.4 & 1.00024 (Stable) \\
\hline & 273.5 & 1.00060 (Stable) \\
\hline
\end{tabular}

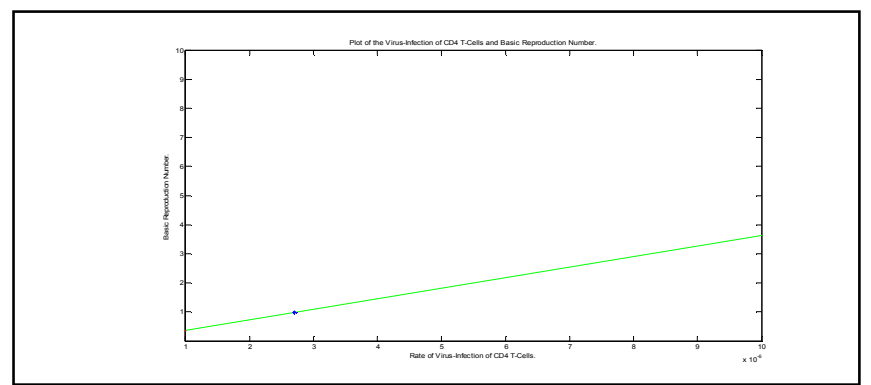

Fig. 1. Plot of the lower possible stability limit of Infection rate of CD4+ TCells with virus for the ODE model.

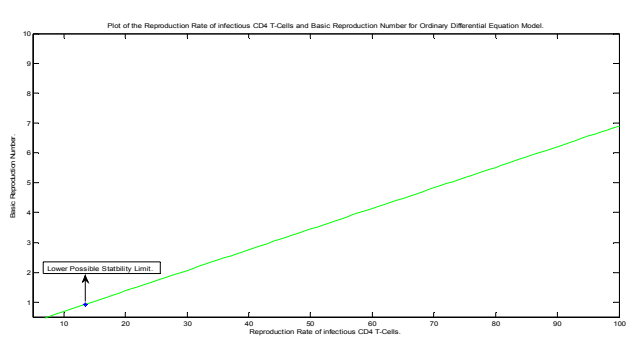


Fig. 2. Plot of the lower possible stability limit for reproduction rate of infectious CD4+ T-Cells for ODE model.

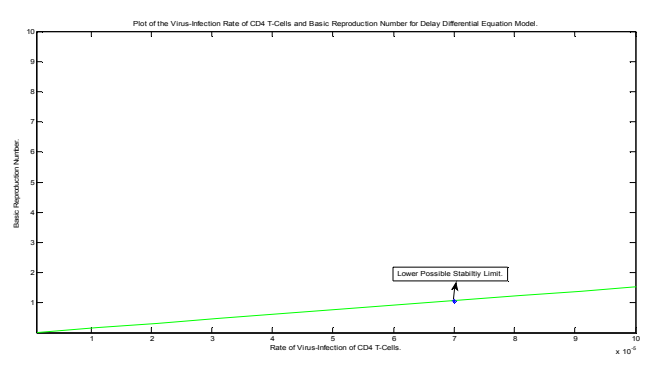

Fig. 3. Plot of the lower possible stability limit of Infection rate of CD4+ TCells with virus for the DDE model.

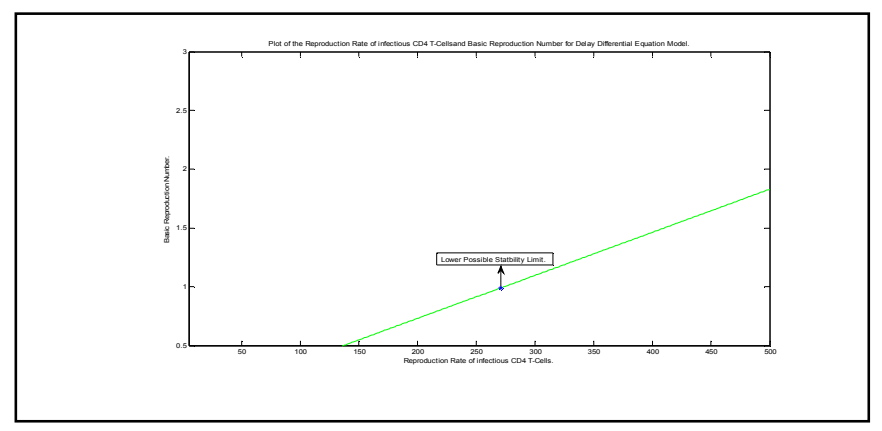

Fig. 4. Plot of the lower possible stability limit for reproduction rate of infectious CD4+ T-Cells for DDE model.

\section{CONCLUSIONS}

The stability of an ODE and DDE epidemic models of the $\mathrm{HIV}$ infection of $\mathrm{CD}^{+}$T-Cells was studied. The research investigated the lower possible stability limits for the infection rate of $\mathrm{CD}^{+}$T-Cells with HIV virus and the reproduction rate of infectious $\mathrm{CD}^{+} \mathrm{T}$-Cells, respectively. The research is significant, for every useful system needs to be stable. The main contribution is the study of stability of the ODE and DDE models of the HIV infection of $\mathrm{CD} 4^{+} \mathrm{T}$-Cells with virus.

\section{ACKNOWLEDGMENT}

This research is supported by Research Management Centre - UTM and Malaysian Organization High Education (MOHE) Grants through votes 4F127 and 07J77. The authors are thankful to financial support.

\section{REFERENCES}

[1] R. J. De Boer, and A. S. Perelson, "Target cell limited and immune control models of HIV infection: a comparison," J.Theor. Biol., vol. 190, no. 3, pp. 201-214, 1998.

[2] T. B. Kepler, and A. S. Perelson, "Cyclic re-entry of germinal center $B$ cells and the efficiency of affinity maturation," Immunol. Today., vol. 14, no. 8, pp. 412-415, 1993.

[3] J. K. Percus, O. E. Percus, and A. S. Perelson, "Predicting the size of the T-cell receptor and antibody combining region from consideration of efficient self-nonself discrimination," Proc. Natl. Acad. Sci. U. S. A., vol. 90, no. 5, pp. 1691-1695, 1993.

[4] X. Zhou, X. Song, and X. Shi, "A differential equation model of HIV infection of CD4_T-cells with cure rate," J. Math. Anal. Appl., vol. 342, no. 2, pp. 1342-1355, 2008.

[5] A. R. McLean, M. M. Rosado, F. Agenes, R. Vasconcellos, and A. A. Freitas, "Resource competition as a mechanism for B cell homeostasis," Proc. Natl. Acad. Sci. U. S. A., vol. 94, no. 11, pp. 5792-5797, 1997.

[6] X. Song, and A. U. Neumann, "Global stability and periodic solution of the viral dynamics," J. Math. Anal. Appl., vol. 329, no. 1, pp. 281-297, 2007.

[7] A. L. Lloyd, "The dependence of viral parameter estimates on the assumed viral life cycle: limitations of studies of viral load data," Proc. Royal Soc. B., vol. 268, no. 1469, pp. 847-854, 2001.

[8] D. Li, and W. Ma, "Asymptotic properties of a HIV-1 infection model with time delay," J. Math. Anal. Appl., vol. 335, no. 1, pp. 683-691, 2007.

[9] A. R. McLean, and T. B. L. Kirkwood, "A model of human immunodeficiency virus infection in T helper cell clones," J. Theor. Biol., vol. 147, no. 2, pp. 177-203, 1990.

[10] A. R. McLean and M. A. Nowak, "Models of interactions between HIV and other pathogens," J. Theor. Biol., vol. 155, no. 1, pp. 69-86, 1992.

[11] J. E. Mittler, B. Sulzer, A. U. Neumann, and A. S. Perelson, "Influence of delayed viral production on viral dynamics in HIV-1 infected patients," Math. Biosciences., vol. 152, no. 2, pp. 143-163, 1998.

[12] J. Yang, X. Wang, and F. Zhang, "A differential equation model of HIV infection of CD4+ T-Cells with delay," Discrete. Dynamics. Nature Soc., vol. 2008, pp. 1-16, 2008.

[13] A. S. Perelson, P. Essunger, Y. Cao, et al., "Decay characteristics of HIV-1-infected compartments during combination therapy," Nature., vol. 387 , no. 6629 , pp. 188-191, 1997.

\section{Creative Commons Attribution License 4.0 (Attribution 4.0 International, CC BY 4.0)}

This article is published under the terms of the Creative Commons Attribution License 4.0 https://creativecommons.org/licenses/by/4.0/deed.en_US 